\title{
A Short History of Breast Augmentation and Possible Future
}

\section{Perspectives}

\section{Di Rosa L* \\ Department of Oncological Surgery, University of Palermo, Italy}

*Corresponding author: Luigi Di Rosa, Department of Oncological Surgery, University of Palermo, Via G.B. Lulli 42, 90145 Palermo, Italy, Tel: 091-9824530; E-

\section{Editorial}

Volume 1 Issue 1

Received Date: September 25, 2017

Published Date: October 04, 2017 DOI: $10.23880 /$ ijtps-16000102 mail: luigidirosa@gmail.com

\section{Editorial}

According to the annual survey of the international society of aesthetic plastic surgery, in 2016, 1,649,871 breast augmentation procedures were performed in the world, in particular 1,449,337 silicone breast implants and the remaining were fat transfer procedures and saline implants, with a trend steadily increasing from year to year, it will suffice to consider that between 2015 and 2016 the increase in silicone prostheses was $11 \%$, and that of fat transfer was $22 \%$. The country where this surgery is most required are United States of America $20.1 \%$ of all surgical procedures, followed by Brazil (13.2\%) and Russia (5.1\%) [1]. Despite the Breast Augmentation being one of the most accomplished surgery in the world, quite surprisingly, is a very recent surgical procedure compared with other such as eye or orthopedicsurgery that are rooted in history with historical testimonies of thousands of years ago. Indeed, the attention of the scientific community about breast atrophies or asymmetries was rather rare until the late nineteenth and early twentieth century's, one of the most innovative surgeon in this field, Passot, in 1930noted that while he himself had performed more than 180 operations for hypertrophy, he had seen only 8 procedures performed to correct atrophy [2].

The first sources date back to the last part of the nineteenth century, with the first attempts to fill and remodel the breast with autologous tissue (fat transfer). According to literature, the very first attempt was performed in 1895by Vincenz Czerny (1842 - 1916), a German surgeon that used a lipoma taken from lumbar region of a patient and transferred it to fill the defect in a breast that had been treated for fibrocystic mastitis.
According to the author, operation was successful and the lipoma was not reabsorbed but it is said that has stopped its growing [3].

In following years same technique was used by other authors and most of them anecdotally noticed fat tissue growing stopped after transplantDuring the same period, the firsts attempt of free transfer fat tissue for breast augmentation were made, with a good approximation we can attest that the first was performed by Gustav Adolf Neuber, for correcting hypotrophic breast $[4,5]$. We have to wait until 1925when Erich Lexer (1867 - 1937) published his 20 years of experience of free fat tissue transfer in augmentation mammoplasty from a cosmetic point of view, then in 1930, Raymond Passot (1894 1947) published his works on fat transfer taken from abdomen and buttocks and John Watson (1914 - 2009) in 1959 wrote a review on the application of free fat transfer in mammoplasty [6-10].

Both Lexer, Passot and Watson in different period of time stated that grafts had to be small in size in order to avoid necrosis and complications but vascular theory on fat survival was yet to come.Fat tissue was not the only method used in the past to obtain an additive mammoplasty, An Austrian surgeon, Robert Gersuny (1844 - 1924) described the injection of foreign material (paraffin), and then other surgeons tried to use different materials, such as vegetables oils, lanolin, liquid silicone, and even bee wax [11].

Shortly, side effects such as paraffinomas and other complications made clear that those materials were not 


\section{International Journal of Transplantation \& Plastic Surgery}

the solution.

Industrial development after Second World War, led to creation of many synthetic polymers, so surgeons begun to utilize sponges of polyvinyl alcohol or polyethylene molded to mimic the shape of the breast [11-14]. During 1950s and 1960s many implants were positioned, but again, problemsof abnormal scarring, capsular contracture, and tissue reaction put an end to the use of sponges for breast augmentation. We have to wait until 1963, when Dr Thomas Cronin (1906 - 1993) together with his resident Dr Frank Gerow invented the first implant made of silicone gel, paving the way for a revolution in the field of plastic, reconstructive and aesthetic surgery. The first generation models were made of a silastic rubber wall and a viscous filling gel inside; unfortunately these prostheses were quite fragile, often leading to ruptures and silicone leakage which led to capsular contracture and skin deformities [15]. early prostheses problems in late seventies and eighties led to a witch hunt against silicone implants in the USalso because suspects about a possible carcinogenicity of these implants began to circulate, so that saline implants firstly used by H. G. Arion in 1965,dominated markets for over 14 years. Firsts saline implants were silicon prostheses inflated with physiological solution not very different from the ones used nowadays [16].

It was only in 2000 that meta-analysis stated that silicone implants were not armful for connective tissues, but only in 2006 FDA cleared use of silicon prostheses for breast augmentation $[11,17]$.

Author personal opinion is that future of breast augmentation will be linked to the new three-dimensional reconstruction techniques and bioprinting which will enable the construction of breast implants through a biocompatible scaffold on which the own patient's cells will be sown and let grow before being implanted again in patient's body, avoiding, hopefully, the problems associated with the alloplastic materials [18,19].

Plastic surgery has always been a field of great and continuous innovations, the same spirit of research and thirst for knowledge to exist in new generations of surgeons and researchers, and we can expect great innovations in this field in the near future.

\section{Acknowledgement}

Author wants the author wants to thank Prof. Juan Carlos Pavani MD plastic surgeon from Buenos Aires for his key points so useful for the implementation of this paper.

\section{References}

1. ISAPS Global Statistics

2. Passot R (1930) AtrophieMammaire. La Presse Medicale 37: 627-628.

3. Czerny V (1895) Plastische Ersatz der Brust-druse durcheinlipom. Chir Kong Verhandl 2: 216.

4. Bier AKG (1910) Fettransplantation. Chir Kong Verhan-dl 1: 189.

5. Neuber G (1893) Fettransplantation. Chir Kong Verhan- dl 1: 66.

6. Lexer E (1927) Diefreien Transplantationen. Neue deutsche chirurgie, 26. Bd. a-b.

7. Hinderer UT, del Rio JL (1992) Erich Lexer's mammoplasty. Aesthetic Plast Surg 16(2): 101-107.

8. Passot R (1931) La Chirurgie Esthétique Pure. Doin, Paris, pp: 222-259.

9. Passot R (1930) Atrophie mammaire: refection esthetique par la greffe graisseuse épiploïque. PresseMéd. 37: 627-629.

10. Watson J (1959) Some observations on free fat grafts: with reference to their use in mammaplasty. Br J Plast Surg 12: 263-274.

11. Champaneria MC, Wong WW, Hill ME, Gupta SC (2012) The evolution of breast reconstruction: a historical perspective. World J Surg 36(4): 730-742.

12. Grindlay JH, Waugh JM (1951) Plastic sponge which acts as a framework for living tissue; experimental studies and preliminary report of use to reinforce abdominal aneurysms. AMA Arch Surg 63(3): 288297.

13. Pangman J, Wallace RM, Hills B (1995) The Use of Plastic Prostheses in Breast Plastic and Other Soft Tissue Surgery. West J Surg Obstet Gynecol 63(8): 503-512.

14. Neuman Z (1956) The Use of the Non-Absorbable Polyethylene Sponge, 'Polystan Sponge,' as a Subcutaneous Prosthesis; an experimental study in rats. Br J Plast Surg 9(3): 195-199. 


\section{International Journal of Transplantation \& Plastic Surgery}

15. Brown JB, Fryer M, Lu M (1954) Polyvinyl and Silicone Compounds as Subcutaneous Prostheses: Laboratory and Clinical Investigations. AMA Arch Surg 68(6): 744-751.

16. Santoni RugiuP, Sykes PJ (2007) A history of Plastic Surgery. Springer-Verlag Berlin, Heidelberg, pp. 153155.

17. Arion HG (1965) Prosthesis Retromammaires. CR Soc Fr Gynecol 35: 427-431.

18. Janowsky EC, Kupper LL, Hulka BS (2000) Metaanalyses of the relation between silicone breast implants and the risk of connective-tissue diseases. N Engl J Med 342(11): 781-790.

19. Jipeng Li, Mingjiao Chen, Xianqun Fan, Huifang Zhou (2016) Recent advances in bioprinting techniques: approaches, applications and future prospects. J Transl Med 14: 271.

20. Thomas DJ (2017) 3D bio printing as a solution for engineering the nipple areola complex for breast cancer reconstruction. Int J Surg 41: 14-15. 